\title{
Exploring Social Presence Theory in The Online Classroom: The Case for Online Presence
}

Mohd Ali Muhamad Don, Mohd Rilizam Rosli, Mohd Shukri Mohd Senin, Mohd Farhan Ahmad

To Link this Article: http://dx.doi.org/10.6007/IJARBSS/v12-i1/11440

DOI:10.6007/IJARBSS/v12-i1/11440

Received: 07 November 2021, Revised: 10 December 2021, Accepted: 28 December 2021

Published Online: 03 January 2022

In-Text Citation: (Don et al., 2022)

To Cite this Article: Don, M. A. M., Rosli, M. R., Senin, M. S. M., \& Ahmad, M. F. (2022). Exploring Social Presence Theory in The Online Classroom: The Case for Online Presence. International Journal of Academic Research in Business and Social Sciences, 12(1), 26-40.

Copyright: (C) 2022 The Author(s)

Published by Human Resource Management Academic Research Society (www.hrmars.com)

This article is published under the Creative Commons Attribution (CC BY 4.0) license. Anyone may reproduce, distribute, translate and create derivative works of this article (for both commercial and non0-commercial purposes), subject to full attribution to the original publication and authors. The full terms of this license may be seen at: http://creativecommons.org/licences/by/4.0/legalcode

Vol. 12, No. 1, 2022, Pg. $26-40$

Full Terms \& Conditions of access and use can be found at http://hrmars.com/index.php/pages/detail/publication-ethics 


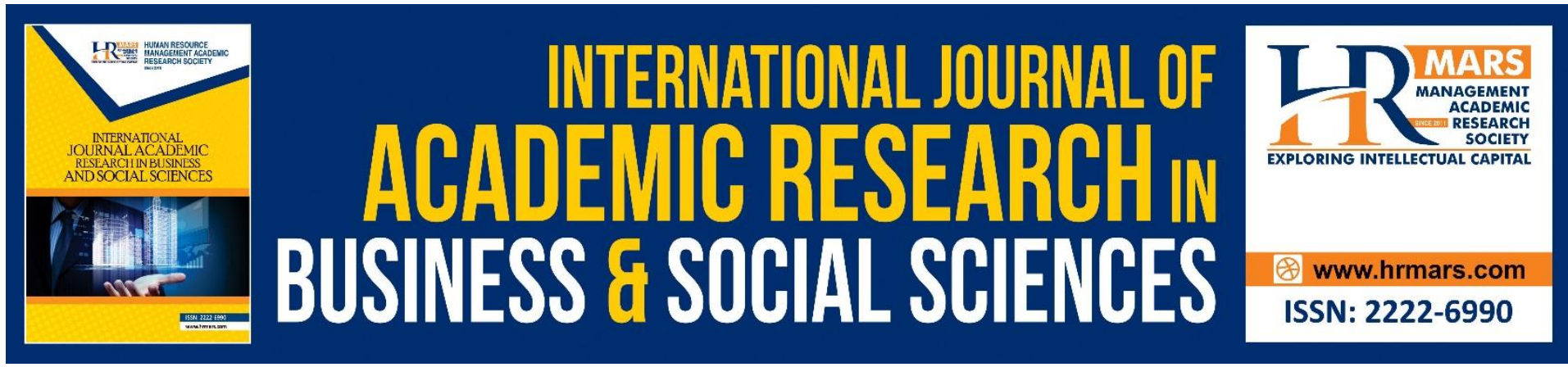

\title{
Exploring Social Presence Theory in The Online Classroom: The Case for Online Presence
}

\author{
Mohd Ali Muhamad Don, $\mathrm{PhD}^{1}$, Mohd Rilizam Rosli, $\mathrm{PhD}^{2}$,
} Mohd Shukri Mohd Senin, $\mathrm{PhD}^{3}$, Mohd Farhan Ahmad ${ }^{4}$

1,2,3 Senior Lecturer, Academy of Contemporary Islamic Studies (ACIS), University Teknologi

MARA Cawangan Johor Kampus Pasir Gudang, Malaysia, ${ }^{4}$ Lecturer, Academy of

Contemporary Islamic Studies (ACIS), University Teknologi MARA Cawangan Johor Kampus

Pasir Gudang, Malaysia.

Email: 73khawarizmi@gmail.com, rilizam@uitm.edu.my,shukrisenin@uitm.edu.my, mohdf389@uitm.edu.my

\begin{abstract}
Online classroom or virtual classroom is a digital learning environment that allows teachers and students to connect online learning in real time. Online learning is a form of distance learning or distance education, which has long been a part of the American education system, and it has become the largest sector of distance learning in recent years. In this regard, many governments took measures in order to avoid spreading the virus and to ensure the continuity of the educational process, and universities worldwide adopted online classroom learning. To further tackle the alarming infection rate of the deadly coronavirus, the Malaysian government had issued a movement control order (MCO) that fully dampened the learning institutions' operational activities so that online learning became one of the solutions to perform teaching and learning activity. In this paper Author wants to identify teacher presence influences on online teaching and interactivity influence cognitive presence. The social presence influences social context also tried to identify in this paper. To obtain the data of this research the quantitative research method will be used. Questionnaire was given to the students of MARA University of Technology, Johor, Malaysia and the sample of 38 students was analysed with SPSS software. The findings show that the instructor clearly communicated significantly for online learning activities and learning activities helped students to construct the explanations and solutions. So that within the social presence theory the online classroom can effectively be conducted due to pandemic situations and the e learning education system.
\end{abstract}

Keyword: Social Presence Theory, Online Classroom, Teaching Presence, Cognitive Presence and Social Presence

\section{Introduction}

Background of Study

Online learning is not new in an education field where this way of education has been practiced before mostly in higher institutions. However, it became crucial recently after the 
pandemic of COVID-19 hit the world. Since then, the use of online learning has become fundamental to all students despite their level of studies. It is estimated that more than 421 million students have been affected by the closure of educational institutions involving 39 countries while 22 countries have decided to run their operations on a half time basis (Tam \& El Azhar,2020).

In Malaysia, when the government announced the implementation of Movement Control Order (MCO) starting $16^{\text {th }}$ March 2020, all institutions from government and private sector started to use online learning as a medium to continue the education process. A study conducted by Hale \& Yasemin (2017), aimed to identify the reason why learners choose online learning. This qualitative study was conducted with 944 participants from undergraduate level and 178 participants from graduate level who take online learning classes. Coding was conducted according to the participant's comment. The codes and themes were generated by the researchers themselves. From the finding, there are ten themes that lead the participant to choose online learning. Having a full-time job with a high tempo of working life forcing them to choose a distance education program.

Another reason is accessibility and flexibility where online learning is more independent in terms of location and time. Next is individual responsibility where there are participants who want to further their study but at the same time bond to responsibility in taking care of children, parents, siblings and other family members in need. Individual difficulties are also part of the reason for choosing online learning as this medium of study consumes lower financial expenses compared to traditional ways. Another reason that attracts the participants is the learning environment itself. Online learning is said to be systematic, coordinated, repeatable, containing visual audio presentations and also allowing the students to access virtual classroom activities. Next is Physical distance where there are participants whose job requires them to move from one place to another. There is also a reason of having a second degree, institutional prestige, aging and disability

According to Verawadina et al (2020), online learning is a method of learning that allows the learning process to take place anywhere and anytime even being outside the lecture period. On the other hand, online learning is also defined as a learning experience in a synchronous or asynchronous environment using multiple devices with access to the internet. Synchronous environment occurs when students and instructors attend a live lecture. There are real time instructions and students can get instant feedback on matters asked. In contrast with asynchronous where the learning content is not available in a form of live lecture thus hinder students from getting instant feedback (Dhawan, 2020). There are a number of platforms that can be used for online learning processes like Google classroom, Microsoft Teams, Webex and a platform through social media like WhatsApp, Telegram and YouTube (Chung et al, 2020).

\section{Statement of Problem}

Online learning is a new phenomenon in learning methods. The face -to -face learning method was found to be quite difficult to implement due to the spread of pandemic covid 19 worldwide. The best alternative in continuing the learning agenda in this pandemic season is through online learning methods. Several studies have been conducted on the effectiveness of online learning in terms of its success or challenges.

Among the examples of research findings that state online learning achieves a high level of effectiveness was as stated by Siti (2021) who found that the level of effectiveness of online 
learning and teaching can be interpreted at a high level because the total mean score for her study is 3.8. Factors that influence the effectiveness of online learning are the motivational strategies used by lecturers (mean 3.93), aspects of feedback from lecturers (mean 3.89) and the design of online learning portals (3.83). According to Salleh (2021), the effectiveness of online learning is also influenced by the availability of infrastructure. His study found that the readiness of students for online learning is high because they have sufficient equipment and facilities such as computers, laptops, Internet and software to participate in online learning.

However, there are also studies that show otherwise. Ishak \& Talaat (2020) found that students' readiness to participate in online learning is low with a mean score of 2.67 which means students are more prepared for face -to -face learning than online learning. In a study conducted by the Ministry of Education Malaysia on the readiness of students in online learning involving a total of 670,118 respondents including parents of 893,331 students, the Ministry of Education Malaysia found that 36.9 percent of students do not have electronic devices to enable them to learn online (Mohd, 2020). Malaysian Senior Minister (Education), Dr Radzi Jidin stated that the ministry is also aware of weaknesses in the implementation of online learning which has the effect that students will face difficulties in achieving the minimum level of proficiency in each subject learned (Rohaniza et al., 2020). Thus, this unavailability is the cause of the lack of effectiveness of online learning.

By looking at the studies that show the effectiveness and lack of effectiveness of online learning above, then this study would like to look at different aspects related to online learning, that is, aspects of Online Presence (teaching, social and cognitive presence). Thus, this study tries to obtain different research results from previous studies related to online learning.

\section{Objective of Study and Research Questions}

Generally, this study explores learners' perception of online learning. specifically, this study is done to answer the following questions;

1.1.1 How does teacher presence influence online teaching?

1.1.2 How does interactivity influence cognitive presence?

1.1.3 How does social presence influence social context?

\section{Literature Review}

Social Presence Theory

The social presence theory explores the sense of being with one another in the online interface. This theory states that computer-based communication is lower in social presence than in face-to-face communication. This would mean that online classes would bear less (or no) social presence to learners. However, Tu \& Mclsaac (2002) argued that in the context of online learning, social presence rests upon three dimensions (figure 1); (a) social context, (b) online communication, and (c) interactivity. This means that as long as the environment facilitates learning in a social context and the learning involves interactivity, then learners can feel the social presence. In addition to that, Sukimin et al (2021) also found that learners thrive when there is active learning in the classroom. Active learning gives the learners a feeling of presence in the virtual classroom. 


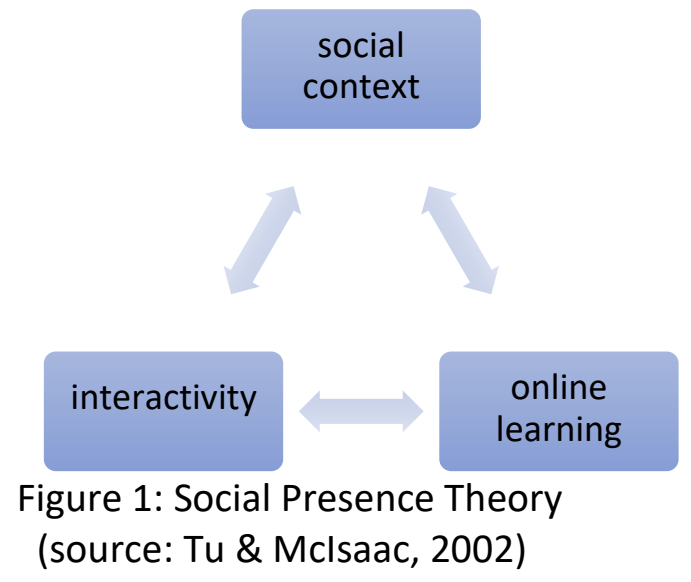

Past Studies

Past Studies in Disadvantage sin Online Learning

There have been several past studies on the disadvantages of online learning. First a study by Zounek \& Sudicky (2013) that made a comparison between the pros and cons of online learning found that students often struggle to utilize various time-management, presentation, word-processing, collaboration, and other kinds of tools for personal learning purposes, technology-enhanced learning also causes negative resentments for students to organize workload and learn independently, issue of communication and information overload may cause distraction for students focused and concentrated to learning and task solving. The study using data from this library research source found that the pros and cons of online technologies in education is complex and the parties involved should have an openminded view of education technology implementation and reflecting the best practices in the learning environment.

Next there is a study by Salleh et.al (2020) who studied about online learning in Malaysia, the advantages and disadvantages of online learning, how to overcome the disadvantages of online learning and why online learning is the good choice to conduct class for tertiary education during Movement Control Order (MCO) in Malaysia. This study is also a qualitative study that reports research data based on content analysis methods. Findings show that there are some disadvantages of online learning such as no self-discipline among the student, no face-to-face interaction between students and lecturer, lack of input from lecturer, difficulty to do good on line learning, lack of facilities to support online learning and hard to resolve the difficulties. Author stated that online education is a method that can benefit both lecturers and students especially during MCO, where most of the education institutions have to close due to Covid-19 pandemic. In other ways the disadvantages problems occur must be thoroughly improved to ensure that online classes achieve the objectives.

Past Studies in Interaction/Engagement during Online Learning

The aspect of student involvement during online learning is a really important matter in making sure that the objectives of teaching a particular subject is fully mastered by them. According to Julie \& Melanie (2016), the role of a lecturer is not only to continuously deliver the lessons to students online, but also to motivate and encourage them to continue on with their studies. In addition, the results of a study conducted by Mahiswaran et al (2020) showed 
that student interactions via online learning were often interfered by the presence of family members while the student was in the middle of a teaching session.

Studies have shown that most students were not interacting as much during online learning. There were not that many questions asked either during the live lessons or after the lessons even when they were offered a chance to ask questions. The level of student mastery can only be seen through student interaction in online classes but it can only be measured after they were given a number of assignments related to the topics previously discussed (Waleed, et al., 2018).

According to Mohammed et al (2020), students interacted more when they were assigned with exercises in the form of games and quizzes by the lecturer, such as kahoot and so on because it could stimulate students' interest to give a good prompt response. Student interaction will increase even more if the lecturer uses the WhatsApp platform, especially if there happens to be any problems that arise after the learning session.

\section{Conceptual Framework}

This study is rooted from social presence theory by Tu \& Mclsaac (2002). The three factors in the social presence theory (a) social context, (b) online communication, and (c) interactivity is scaffolded onto the three types of presence in online learning by Arbaugh et al., (2008). Firstly, the success of online learning depends on the activities planned by the teacher. According to Taib, et al (2021), teacher presence is the binding factor that holds the learner's motivation to sustain in the online class. Next, interactivity among learners in the online classroom helped provide the cognitive presence in an online class. Finally, the environment and the social context that the teacher set for the online class motivated learners to stay in the online class.

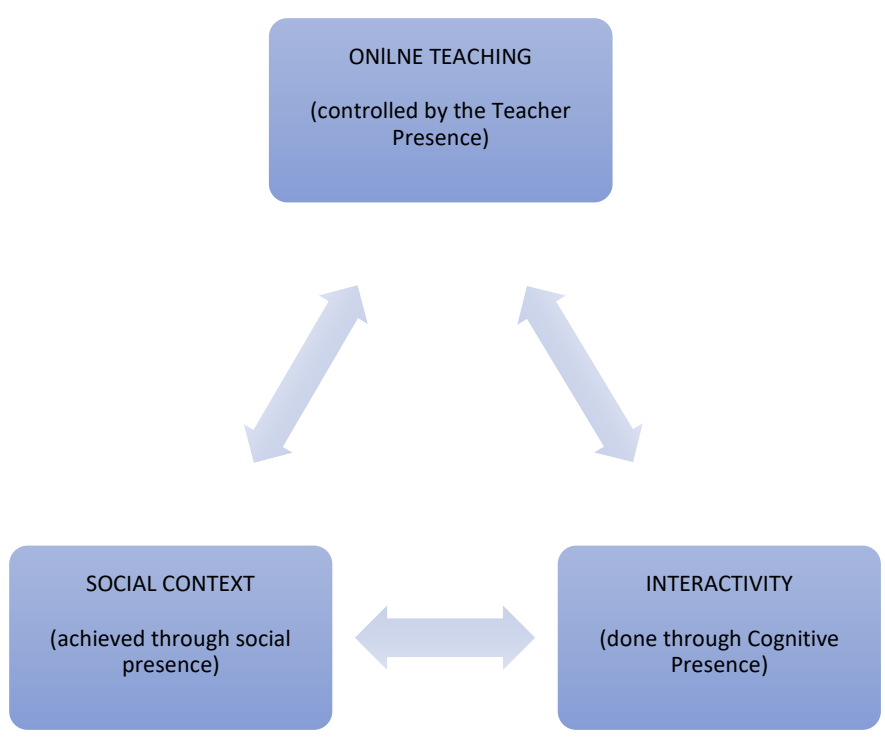

Figure 2- Conceptual Framework of the Study:

Social presence of Online learning

(Source: Tu \& Mclsaac, 2002 and Arbaugh, Cleveland-Innes, Diaz, Ice, Richardson \& Swan, 2008) 


\section{Methodology}

This quantitative study is done to investigate presence in online learning. 83 participants responded to the instrument which is a survey (table 1). The survey is adapted from Arbaugh, Cleveland-Innes, Diaz, Ice, Richardson \& Swan (2008). It has 4 sections. Section A has 4 items on demographic profile. Section B has 13 items on online learning (teaching presence). Section C has 12 items on Interactivity (cognitive presence) and section C has 9 items on social context (social presence).

Table 1-Distribution of Items in Instrument

\begin{tabular}{|l|l|l|}
\hline SECTION & FACTORS & NO OF ITEMS \\
\hline A & DEMOGRAPHIC PROFILE & 4 \\
\hline B & ONLINE LEARNING(TEACHING PRESENCE) & 13 \\
\hline C & INTERACTIVITY (COGNITIVE PRESENCE) & 12 \\
\hline D & SOCIAL CONTEXT (SOCIAL PRESENCE) & 9 \\
\hline & TOTAL & 34 \\
\hline
\end{tabular}

An analysis of the instrument (table 2) revealed a cronbach alpha of .977 thus revealing high internal reliability for the instrument. Data is analysed using SPSS version 26 to reveal percentages and mean scores.

Table 2- Reliability Statistics

\section{Reliability Statistics}

\begin{tabular}{r|r}
$\begin{array}{c}\text { Cronbach's } \\
\text { Alpha }\end{array}$ & N of Items \\
\hline .977 & 34 \\
\hline
\end{tabular}

\section{Findings}

Findings for Demographic Profile

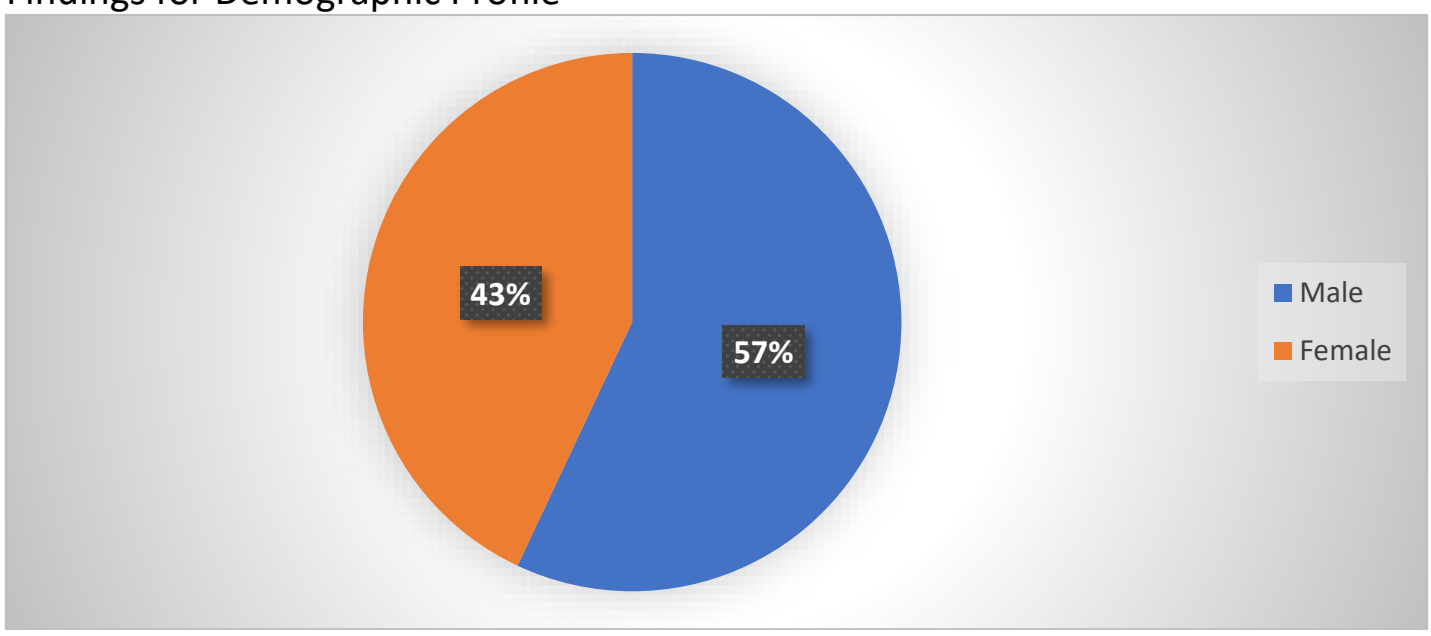

Figure 3-Percentage for Gender

Figure 3 shows that $57 \%$ demographic profile comes from male respondent and others $43 \%$ of respondent comes from female respondent. It concludes that male students are more likely to answer the questionnaire than female students. 


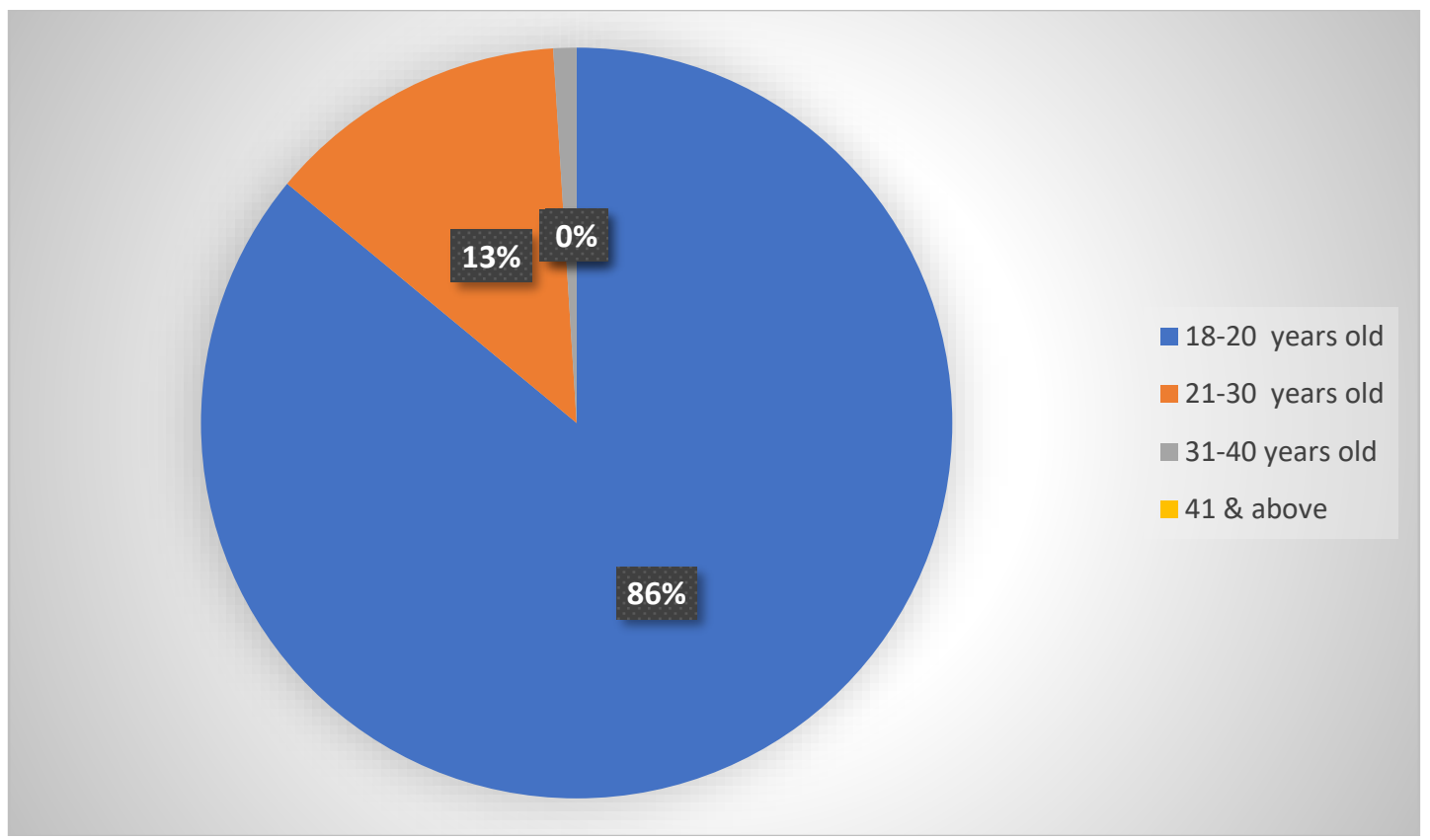

Figure 4-Percentage for Age Group

Figure 4 shows the percentage of respondents for Age Group which was taken from the questionnaire. About $86 \%$ come from the age of 18 to 20 years old. Respondents with age 21 years old to 30 years old recorded $13 \%$ and $1 \%$ for respondents with age of 31 to 40 years old.

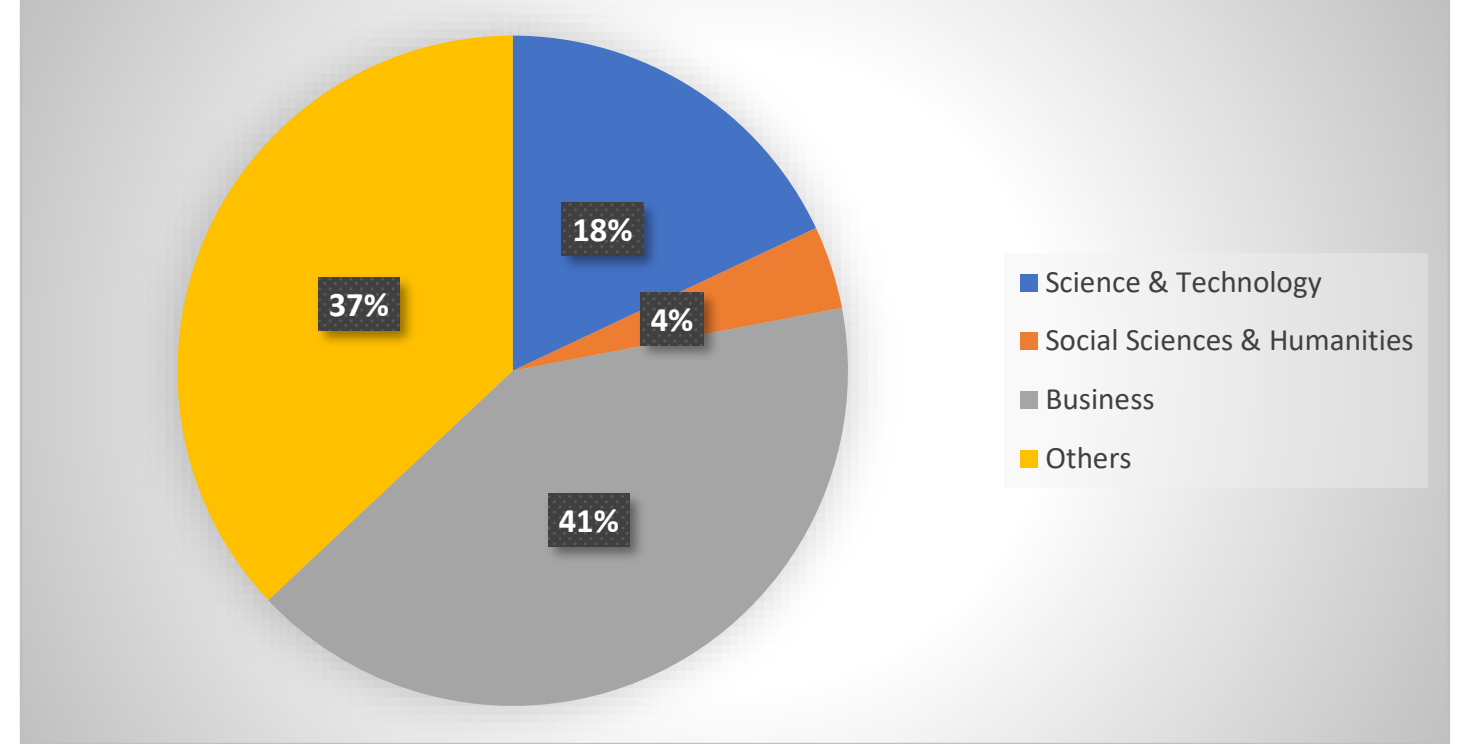

Figure 5-Percentage for Cluster

Figure 5 above shows the percentage of student clusters involved in this study. The largest percentage is from business (41\%), followed by other fields (37\%), science and technology (18\%) and Social Sciences \& Humanities (4\%). 


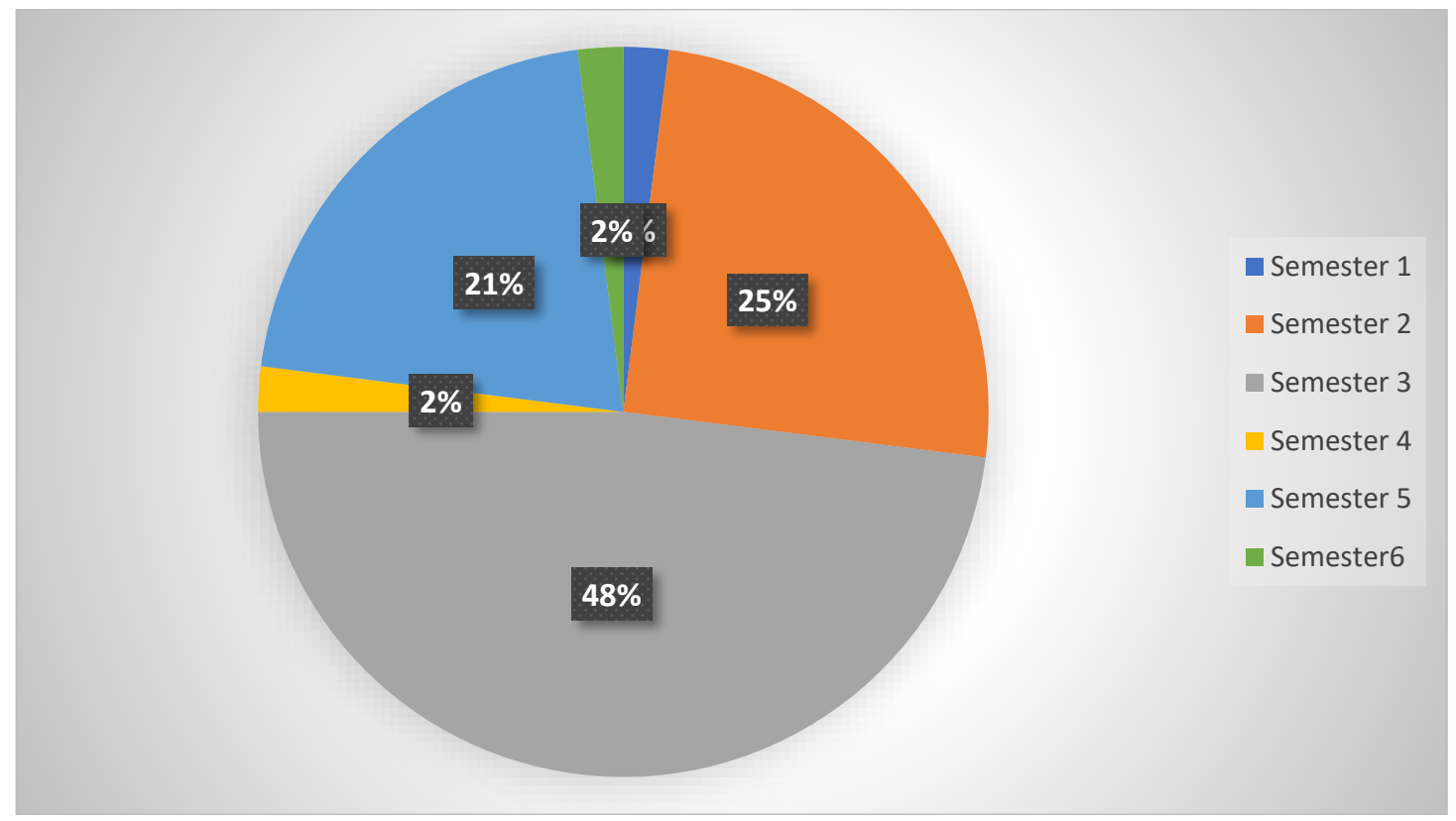

Figure 6-Percentage for Current Semester

Figure 6 above shows students from all semesters involved in this survey. However, semester 3 students are the highest respondents who answered this survey with a total of $48 \%$, followed by semester 2 students by $25 \%$ and semester 5 students by $21 \%$. In addition, there are students in semester $1,4 \& 6$ who also answered this survey with $2 \%$ each. This difference is due to the intake of a large number of students in a particular semester making the number of students who answered this survey also high. Many of the students in semesters 2, 3 and 5 who answered this survey also showed that they were among the students who were affected by the Covid-19 pandemic and had been directly involved through the online learning phase.

Findings for Online Teaching (through teacher presence)

This section presents data to answer research question 1: How does teacher presence influence online teaching? 


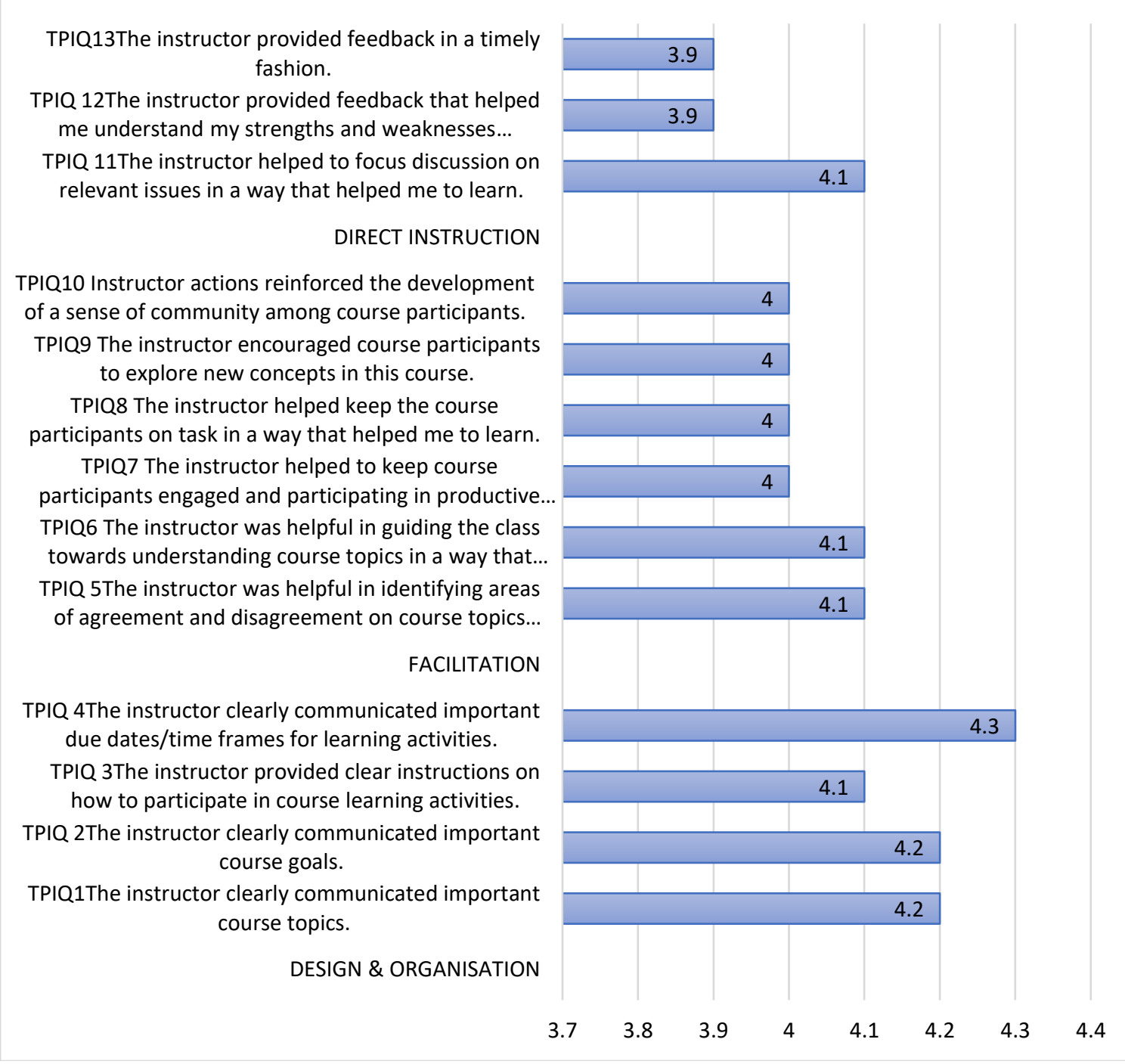

Figure 7-Mean for Online Teaching (Teacher Presence)

The analysis of Figure 7 depicts that the highest mean score was 4.3 with regards to "The instructor clearly communicated important due dates/time frames for learning activities". This indicates that through the medium of online classroom, instructors could easily inform due dates/time of learning activities, while only 3.9 mean score of the sample respondents opined that the instructor provided feedback in a timely fashion. The second highest positive response mean score was 4.2 with regards to "The instructor clearly communicated important due dates/time frames for learning activities" and "The instructor clearly communicated important course goals". On the other hand, the average mean score 4.1 with regard to "The instructor provided clear instructions on how to participate in course learning activities", "The instructor was helpful in identifying areas of agreement and disagreement on course topics that helped me to learn" and "The instructor was helpful in guiding the class towards understanding course topics in a way that helped me clarify my thinking". The researchers also sought to determine the role of lecturer during online classroom. It was found that 4.0 mean score believed that the instructor helped to keep course participants engaged and participating in productive dialogue. At the same level mean score, respondents agreed that the instructor helped keep the course participants on task in a way that helped me to learn. 
As far as "online learning widely adopted in the post pandemic time in developing community" is concerned, the study found that 4.0 mean score believed that Instructor actions reinforced the development of a sense of community among course participants. However, only a 3.9 mean score achieved that the instructor provided feedback that helped me understand my strengths and weaknesses relative to the course's goals and objectives.

\section{Findings for Interactivity}

This section presents data to answer research question 2: How does interactivity influence cognitive presence?

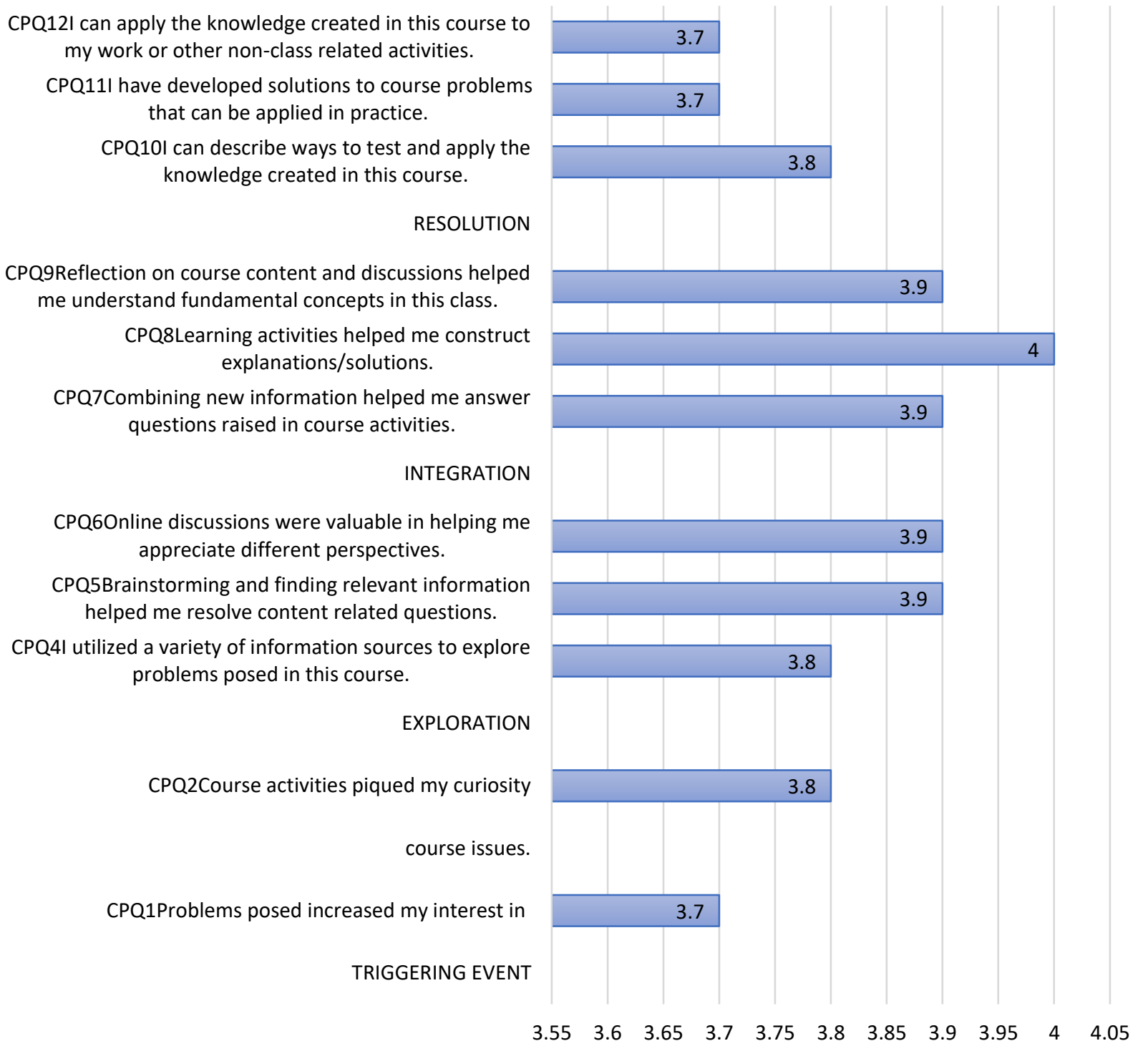

Figure 8 -Mean for Cognitive Presence

Finding based on figure 8 shows a score mean of interactivity through Cognitive Presence based on 12 questions asked. Highest mean is related to question 34 about integration where Learning activities helped me construct explanations/solutions with mean of 4. Mean of 3.9 is recorded for four items which are Exploration like Brainstorming and finding relevant information helped me resolve content related questions (question 31 ) and 
online discussions were valuable in helping me appreciate different perspectives (question 32), Integration like Combining new information helped me answer questions raised in course activities (question 33) and reflection on course content and discussions helped me understand fundamental concepts in this class (question 35).

Meanwhile a mean of 3.8 is recorded for four items which are Triggering Event; Course activities piqued my curiosity (question 28 ) and I felt motivated to explore content related questions (question 29), Exploration; I utilized a variety of information sources to explore problems posed in this course (Question 30) and Resolution; can describe ways to test and apply the knowledge created in this course (question 36). Finally mean of 3.7 is recorded in three items which are Triggering Event; Problems posed increased my interest in course issues and Resolution; increased my interest in course issues (question 37) and I have developed solutions to course problems that can be applied in practice and I can apply the knowledge created in this course to my work or other non-class related activities (question 38).

\section{Findings for Social Context}

This section presents data to answer research question 3 : How does social presence influence social context?

SPQ9 Online discussions help me to develop a sense of collaboration.

SPQ8I felt that my point of view was acknowledged by other course participants.

SPQ7I felt comfortable disagreeing with other course participants while still maintaining a sense of trust.

\section{GROUP COHESION}

SPQ6I felt comfortable interacting with other course participants.

SPQ5I felt comfortable participating in the course discussions.

SPQ4 I felt comfortable conversing through the online medium.

\section{OPEN COMMUNICATION}

SPQ3Online or web-based communication is an excellent medium for social interaction.

SPQ2I was able to form distinct impressions of some course participants.

SPQ1 Getting to know other course participants gave me a sense of belonging in the course.

AFFECTIVE EXPRESSION

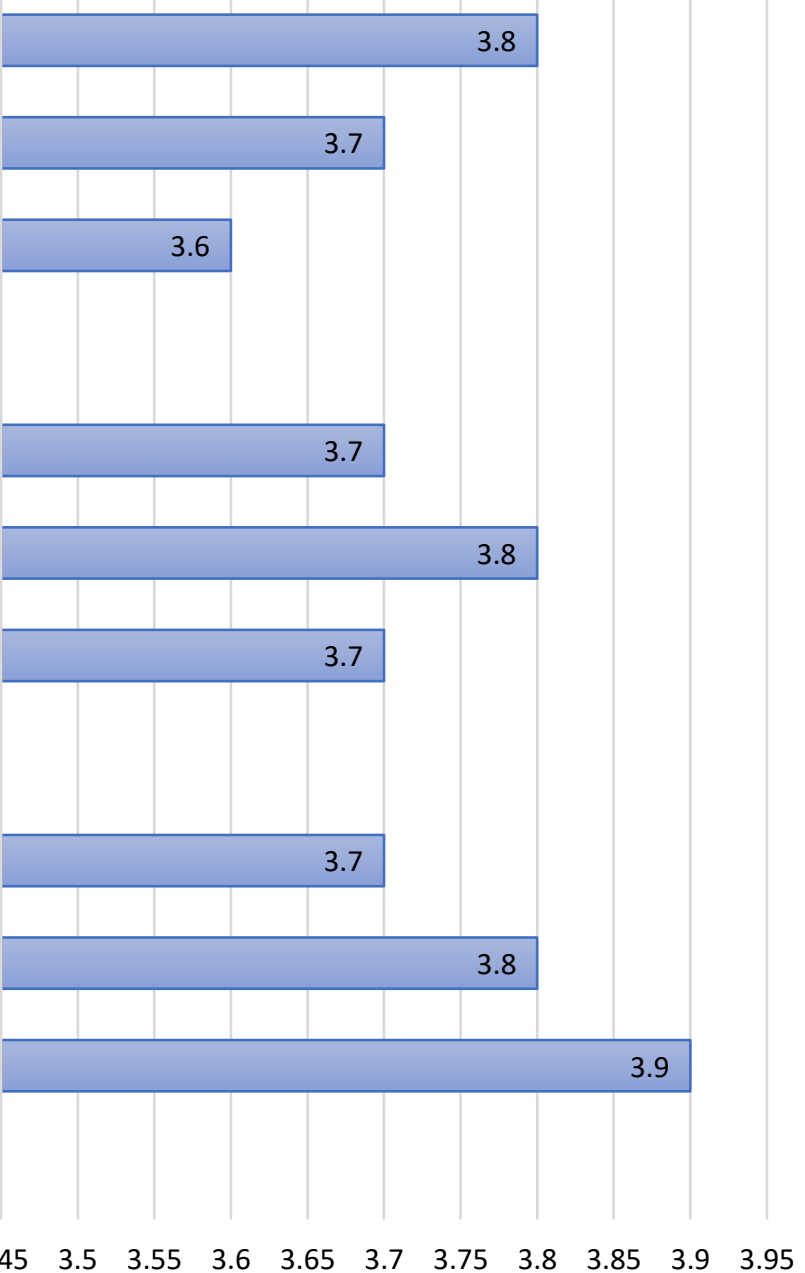

Figure 9-Mean for Social Context 
Figure 9 above shows the mean score for social context of online learning (social presence) which is divided into 3 parts. Affective Expression (SPQ1, SPQ2, SPQ3), Open Communication (SPQ4, SPQ5, SPQ6) and Group Cohesion (SPQ7, SPQ8, SPQ9). The item with highest total mean score for the Affective Expression section was the item "Getting to know other course participants gave me a sense of belonging in the course" with a total mean score of 3.9. This is followed by the item "Was able to form distinct impressions of some course participants" with a total mean score of 3.8 and the item "Online or web-based communication is an excellent medium for social interaction" with a total mean score of 3.7.

Then, the item that got the highest mean score for the Open Communication section was the item "Felt comfortable participating in the course discussions" with a total mean score of 3.8. This is followed by the item" I felt comfortable conversing through the online medium" with a total mean score of 3.7 and item "I felt comfortable interacting with other course participants" that also got a total mean score of 3.7. While the item that got the highest total mean score for the Group Cohesion section was the item "Online discussions help me to develop a sense of collaboration" with a total mean score of 3.8. This is followed by the item "I felt that my point of view was acknowledged by other course participants" that got a total mean score of 3.7 and items "I felt comfortable disagreeing with other course participants while still maintaining a sense of trust" that also got a total mean score of 3.6.

\section{Conclusion}

Summary of Findings and Discussion

The highest mean score (4.3) on the teacher's presence shows that communication between instructors/lecturers according to the planned teaching activities is very important to ensure the success of online learning. This indicates that teacher-guided learning methods are still significant even in online learning activities. This is according to the article written by Mohan (2020) stating that lecturers play a role in encouraging, advising, encouraging and attracting more students in the process of self-learning interaction. The findings of the study of Azizan \& Nasri (2020) also found that teachers gave a positive outlook and were willing to implement online learning during the Covid-19 pandemic period but the challenges faced were constraints for teachers to implement it effectively.

Studies also showed that cognitive presence such as integration of learning activities helps students to resolve the problem and solution (mean 4\%) while course content and discussions help students to understand fundamental concepts of the class online (mean $3.9 \%)$. This is according to the study by Kozan \& Richardson (2014) who found that cognitive presence has a strong effect on the relationship between teaching presence and social presence because the relationship between teaching presence and social presence may disappear when cognitive presence is controlled for.

The social presence also showed that students are compatible with online learningbased education and can collaborate and participate among their friends. It refers to SPQ1 (Getting to know other course participants gave me a sense of belonging in the course) reached mean 3.9\%, SPQ5 (I felt comfortable participating in the course discussions) reached mean 3.8\% and SPQ 9 (Online discussions help me to develop a sense of collaboration) reached mean $3.8 \%$. Other SPQ also showed that social presence is important to conduct online class effectively. Kamal et.al. (2020) concluded that the students became more participative, less anxious and were capable of performing tasks while enjoying their online 
learning sessions. Learners also believed that learning new knowledge and concepts online is not hard. Besides, the learners understood its usefulness as the learning empowered them to work with their peers.

Pedagogical Implications and Suggestions for Future Research

This study explains that Social Presence Theory has a significant impact on the pedagogical aspects of teaching and learning. Where the three components of social presences theory, namely teacher's presence, cognitive presence and social presence if successfully adapted in teaching and learning sessions will make the online classroom can be conducted effectively and achieve the objectives of online learning. Therefore, further studies with a larger number of respondents from various levels of education using the medium of online classroom can be conducted to obtain more detailed data based on differences in students' educational levels; primary, secondary and higher education. For that, lecturers should always be concerned about syllabus and course content, also how to facilitate the students and instruct them to understand the goal and the objective of the course. Similarly, the level of readiness of students to respond and participate online also needs to be strengthened from time to time.

In the future, online learning methods need to be implemented more interactively and encourage the involvement of students as a whole through a variety of more interesting teaching and learning activities. This is important to avoid students getting bored and eventually doing other useless activities. Therefore, further research on interactive learning methods and interaction between teachers and students during online learning sessions can be implemented. This is because with the sophistication of ICT technology and the boom of industry 4.0 based on the Internet of Things, Location Detection and Cloud Computing will further increase the number of online teaching sessions and make it easier to deepen knowledge and in various fields of life.

\section{Reference}

Azizan, S. N. C., \& Nasri, N. M. (2020). Pandangan Guru Terhadap Pembelajaran dalam Talian melalui pendekatan Home Based Learning (HBL) semasa tempoh Pandemik COVID-19. PENDETA: Journal of Malay Language, Education and Literature, 11, 46-57.). https://ojs.upsi.edu.my/index.php/PENDETA/article/view/4446.

Chung, E., Noor, N. M., \& Mathew, V. N. (2020). Are you ready? An assessment of online learning readiness among university students. International Journal of Academic Research in Progressive Education and Development, 9(1), 301-317.

Garrison, D. R., \& Arbaugh, J. B. (2007). Researching the community of inquiry framework: Review, issues, and future directions. The Internet and higher education, 10(3), 157172.

Ilgaz, H., \& Gulbahar, Y. (2017). Why Do Learners Choose Online Learning: The Learners' Voices. International Association for development of the information society.

Ishak, A. A., \& Talaat, A. Z. M. A. (2020). Pembelajaran atas Talian: Tinjauan terhadap Kesediaan dan Motivasi dalam kalangan pelajar Diploma Logistik dan Pengurusan Rantaian Bekalan, Politeknik Seberang Perai, Pulau Pinang. Jurnal Dunia Pendidikan, 2(4), 68-82.

Kamal, A. A., Shaipullah, N. M., Truna, L., Sabri, M., \& Junaini, S. N. (2020). Transitioning to online learning during COVID-19 Pandemic: Case study of a Pre-University Centre in 
Malaysia. International Journal of Advanced Computer Science and Applications, 11(6).). https://philpapers.org/rec/KAMTTO-8 .

Kozan, K., \& Richardson, J. C. (2014). Interrelationships between and among social, teaching, and cognitive presence. The Internet and higher education, 21, 68-73.

Rathakrishnan, M. (2020). COVID-19 ubah pengajaran dan pembelajaran dari rumah. Berita Harian. Malaysia

Edition

https://www.bharian.com.my/rencana/komentar/2020/07/710464/covid-19-ubahpengajaran-dan-pembelajaran-dari-rumah.

Mohd, N. P. (2020). Tiada peranti sukarkan pembelajaran dalam talian. BH Online. https://www.bharian.com.my/berita/nasional/2020/07/711421/tiada-perantisukarkan-pembelajaran-dalam-talian.

Rohaniza, I., Mohd, I. I., Zanariah, A. M. (2020). PdP dalam talian kurang berkesan. BH Online. https://www.bharian.com.my/berita/nasional/2020/07/706183/pdp-dalam-taliankurang-berkesan.

Salleh, F. I. M., Ghazali, J. M., Ismail, W. N. H. W., Alias, M., \& Rahim, N. S. A. (2020). The impacts of COVID-19 through online learning usage for tertiary education in Malaysia. Journal of Critical Reviews, 7(8), 147-149.). http://www.jcreview.com/fulltext/1971590739143.pdf.

Salleh, M., Jamaludin, M. F., Safie, N. S. M., \& Yusof, J. M. (2021). Tinjauan Keberkesanan Pembelajaran Secara dalam Talian Ketika Pandemik Covid-19: Perspektif Pelajar Sains Kejuruteraan Politeknik Ibrahim Sultan. Jurnal Dunia Pendidikan, 3(1), 374-384.

Hassan, S. A. A. (2021). KEBERKESANAN PEMBELAJARAN DAN PENGAJARAN DALAM TALIAN (EPEMBELAJARAN) TERHADAP PEMBELAJARAN PELAJAR DI KOLEJ KOMUNITI HULU LANGAT. International Journal of Humanities Technology and Civilization, 1-14.

Sukimin, I. S., Rahmat, N. H., Sim, M. S., Arepin, M., Abidin, N. S. Z., \& Haron, H. (2021). An Investigation of Mediational Process in Social Learning during Online Language Learning. International Journal of Asian Social Science, 11(5), 240-249.

Taib, N. A. M., Rahmat, N. H., Ismail, S., \& Hassan, O. (2021). TEACHER PRESENCE AS MEDIATOR IN ONLINE LEARNING: THE CASE FOR FRENCH AS A FOREIGN LANGUAGE. European Journal of Foreign Language Teaching, 5(5).

Tam, G., \& El-Azar, D. (3). Ways the coronavirus pandemic could reshape education. In the World Economic Forum.

Tu, C. H., \& Mclsaac, M. (2002). The relationship of social presence and interaction in online classes. The American journal of distance education, 16(3), 131-150.

Verawadina, U., Jalinus, N., \& Krismadinata, W. R. N., \& Simeru, A. (2020). Needs Assessment of E-Learning Vocational Education. International Journal of Innovation, Creativity and Change, 11(4), 262-274.

Zounek, J., \& Sudicky, P. (2013). Heads in the cloud: Pros and Cons of online learning. In International Conference DisCo New technologies and media literacy education, At Prague (pp. 59-62). 